\title{
Fatigue life and surface integrity measurements of EN S355J2 steel used in hydraulic components
}

Jiří Čuban, Ing., Technical University of Liberec, Czech Republic

Olof Calonius, D.Sc. (Tech.), Aalto University, Espoo, Finland

Matti Pietola, prof. D.Sc. (Tech.), Aalto University, Espoo, Finland

Jan Jersák, doc. Ing. CSc., Technical University of Liberec, Czech Republic

This article is aimed at studying the impact of surface integrity - surface roughness, hardness and residual stress - on fatigue performance of EN S355J2 steel. The test specimens were manufactured by turning. A longer fatigue life for the machined components can be obtained by applying such cutting conditions as a low feed rate. The fatigue limit of the specimen with the surface roughness $\operatorname{Ra} 1,6 \mu \mathrm{m}$ is approximately $7 \%$ higher than that of the specimen with $\operatorname{Ra} 3,2 \mu \mathrm{m}$. From the residual stress results it can be seen that the cutting conditions used for producing surface finish $\operatorname{Ra} 1,6 \mu \mathrm{m}$ will introduce mainly compressive residual stress whereas the cutting conditions used for producing surface finish Ra $3,2 \mu \mathrm{m}$ will introduce tensile residual stress. The measurements were carried out at Aalto University at the Departments of Engineering Design and Production and Material Science and Engineering in Espoo. The main purpose of the study is to find proper surface finishing techniques and fatigue improvements for hydraulic components.

Keywords: fatigue life, roughness, hardness, residual stress, Wohler curve (S-N curve)

\section{Acknowledgements}

This paper relates to the work on the SGS research projects which are supported by the Ministry of Education of the Czech Republic. The fatigue tests and the surface integrity measurements were done under the auspices of the DEMAPP project organized by FIMECC Ltd. (Finnish Metals and Engineering Competence Cluster) and funded by TEKES (Finnish Funding Agency for Technology and Innovation) and private companies.

\section{References}

[1] NOVOVIC, D., DEWES, R.C., ASPINWALL, D.K., VOICE, W., and BOWEN, P. The effect of machined topography and integrity on fatigue life, International Journal of Machine Tools \& Manufacture, 2004, Vol. 44, pp. 125 - 134.

[2] FIELD, M., KAHLES, J.F. and CAMMETT J.T. A review of measuring methods for surface integrity, Annals of the CIRP, 1972, Vol. 21 (2), pp. 219-238.

[3] AROLA, D. and WILLIAMS, C.L. Estimating the fatigue stress concentration factor of machined surfaces, International Journal of Fatigue, 2002, Vol. 24, pp. 923 - 930.

[4] SASAHARA H. The effect on fatigue life of residual stress and surface hardness resulting from different cutting conditions of $0.45 \%$ C steel, International Journal of Machine Tools \& Manufacture, 2005, Vol. 45, pp. $131-136$.

[5] VRKOSLAVOVÁ, L., GANEV, N., SANTA-AHO, et al. Comparative Study of Case-hardened and Nitrided Samples by Using Barkhausen Noise Analysis and X-Ray Diffraction, 9th International Conference on Barkhausen Noise and Micromagnetic Testing, 2011, Hejnice, Czech Republic, pp.- ,(in print).

[6] SFS-EN 15305. Nondestructive Testing - Test Method for Residual Stress analysis by X-ray Diffraction, 2008.

[7] NOYAN, I. C. and HORNER, J. T. Residual stress, measurement by diffraction and interpretation, 1987, SpringerVerlag, New York, 276 p.

[8] MURAKAMI, Y., TAKADA, M. and TORIYAMA, T. Super-long life tension-compression fatigue properties of quenched and tempered $0.46 \%$ carbon steel, Journal of the Society of Materials Science, Japan, 1997, Vol.46, No.10, pp.1149 -1154 .

[9] LEE, Y-L. and TAYLOR, D. Stress-based fatigue analysis and design, In Fatigue testing and analysis: theory and practice, 2005, pp. 103-180, Elsevier Butterworth-Heinemann, Burlington, MA, USA, ISBN 0-7506-7719-8.

[10] DAVIM, J. P. (Ed.) Surface Integrity in Machining, Springer-Verlag London, 2010, ISBN 978-1-84882-873-5.

[11] MÁDL, J., HOLEŠOVSKÝ, F. Integrita obrobených povrchů z hlediska funkčních vlastností, Universita J. E. Purkyně, FVTM, 2008, ISBN 978-80-7414-095-2. 